December 2017 Volume 5 Issue 10

www.joucer.com

http://dergipark.gov.tr/jcer

Research Article

\title{
Issues in the Use of Information and Communication Technologies and Unethical Behaviors: An Overview
}

\author{
Selçuk İLGAZ ${ }^{1 *}$ (D) , Akif ÇELEN ${ }^{2}$ (D) \\ Atatürk Üniversitesi, Kazım Karabekir Eğitim Fakültesi, Sosyal Bilimler ve Türkçe Ĕ̆itimi Bölümü, ilgaz@atauni.edu.tr \\ 2 Topsöğ̈̈t Akpınar Ortaokulu Yeşilyurt, Malatya, akif_celen@hotmail.com \\ * Corresponding Author: ilgaz@atauni.edu.tr
}

\begin{tabular}{|c|c|}
\hline Article Info & Abstract \\
\hline $\begin{array}{l}\text { Received: } \quad \text { May 25, } 2017 \\
\text { Accepted: } \\
\text { Online: }\end{array}$ & $\begin{array}{l}\text { The aim of this study is to compare of the effect of Jigsaw and Student } \\
\text { Teams Achievement Divisions methods based on cooperative learning } \\
\text { to sixth grade students' academic achievement in social studies course. } \\
\text { In this study, pretest-posttest control ungrouped experimental model } \\
\text { was used. Research, at } 2014-2015 \text { academic years to } 6 \text {. grade students in } \\
\text { Malatya province, has been made with the implementation the Jigsaw } \\
\text { to Experimental I and Student Teams Achievement Divisions to } \\
\text { Experimental II during } 15 \text { lesson. Achievement Test used as data } \\
\text { collection tool had applicate to experimental groups before experiment } \\
\text { and after experiment, Pretest was analyzed with parametric } \\
\text { Independent Group T Test, Posttest was analyzed with non-parametric } \\
\text { Mann Whitney U Test. According to research results, there was no } \\
\text { significant difference between groups that implemented Jigsaw and } \\
\text { Students Teams Achievement Divisions methods }\end{array}$ \\
\hline open $\mathcal{C}$ access & $\begin{array}{l}\text { To cite this article: İlgaz, S. \& Çelen, A. (2017). Ayrılıp Birleşme ve ÖTBB } \\
\text { (Öğgrenci Takımları Başarı Bölümleri) Yöntemlerinin Sosyal Bilgiler Akademik } \\
\text { Başarıya Etkisinin Karşlaştırılması Journal of Computer and Education Research, } 5 \\
\text { (10), 174-193. https://doi.org/10.18009/jcer. } 315923\end{array}$ \\
\hline
\end{tabular}

\section{Ayrılıp Birleşme ve ÖTBB (Öğrenci Takımları Başarı Bölümleri) Yöntemlerinin Sosyal Bilgiler Akademik Başarıya Etkisinin Karşılaştırılması}

\begin{tabular}{|c|c|}
\hline Makale Bilgisi & Öz \\
\hline $\begin{array}{l}\text { Geliş: } \quad \text { 25 Mayıs } 2017 \\
\text { Kabul: } \quad 28 \text { Temmuz } 2017 \\
\text { Yayın: } \quad \text { 03 Aralık } 2017 \\
\text { Anahtar kelimeler: İşbirliğine dayalı } \\
\text { öğrenme, sosyal bilgiler, ayrılıp } \\
\text { birleşme (Jigsaw), Öğrenci Takımları } \\
\text { Başarı Bölümleri (ÖTBB) }\end{array}$ & $\begin{array}{l}\text { Bu araştırmanın amacı, işbirliğine dayalı öğretim yöntemlerinden olan Ayrllıp } \\
\text { Birleşme ve Öğrenci Takımları Başarı Bölümlerinin 6. sını öğrencilerinin sosyal } \\
\text { bilgiler dersindeki akademik başarıya etkisini karşılaştırmaktır. Araştırmada ön } \\
\text { test son test kontrol grupsuz deneysel model kullanılmıştır. Araştırma, 2014- } \\
2015 \text { eğitim öğretim yılında } 48 \text { altıncı sınıf öğrencisinin katılımılla, Deney I } \\
\text { grubuna Ayrılıp Birleşme ve Deney II grubuna Öğrenci Takımlar Başarı } \\
\text { Bölümleri yöntemlerinin } 15 \text { ders saatinde uygulanmasıyla yapılmıstır. } \\
\text { Araştırmada veri toplama aracı olarak kullanılan Başarı Testi, deney öncesi ve } \\
\text { deney sonrası deney gruplarına uygulanarak Ön Test parametrik testlerden } \\
\text { Bağımsı Grup T Testi ile Son Test ise parametrik olmayan Mann Whitney U } \\
\text { Testi ile analiz edilmiştir. Araştırma sonucuna göre, işbirliğine dayalı Ayrılıp } \\
\text { Birleşme ve Öğrenci Takımları Başarı Bölümleri yöntemlerinin uygulandığ1 } \\
\text { gruplar arasında anlamlı bir fark bulunamamıştır. }\end{array}$ \\
\hline
\end{tabular}


December 2017 Volume 5 Issue 10

www.joucer.com

http://dergipark.gov.tr/jcer

Summary

\section{The Comparison Of The Effect On Social Studies Academic Achievement Of Jigsaw And Students Team Achievement Division (STAD) Methods}

\section{Introduction}

Studies conducted in our country shows that social studies teachers use more lectures, questions and answers, writing and brainstorm methods (Çelikkaya \& Kuş, 2009: 755). According to research shows that the most important obstacle in front of the teacher are lack of time, cannot be taken into consideration individual difference of students and lack of infrastructure in schools (Karacaoğlu \& Acar, 2010; Kuş \& Çelikkaya, 2010). One of the teaching methods that both socialize and increase achievement of the students in lesson is cooperative learning. Cooperative learning began to spread rapidly after the 1980s and is used today in social studies education field as in other areas of education. Cooperative learning has many methods. Intersection of the cooperative learning methods is creation the heterogeneous groups of 4-6 people according to students success, gender and other features by teachers. In all methods based on cooperation, groups have low, medium and high levels successful students (Slavin, 1981: 655). As it is demonstrated that cooperative learning increase students' achievement in social studies by international studies (Slavin, Chamberlain \& Hurley,2001; Adeyemi, 2008), it has also reached similar conclusions in research in our country (Karaoğlu, 1998; Delen, 1998; Özkal, 2000; Çetin, 2002; Katılmış, 2002; Kutay-Atar, 2003; Ersözlü, 2004; Özkümüş (Yetkin), 2010; Göğebakan Yıldız, 2012; Korkmaz Toklucu, 2013). The lack of research on collaborative learning methods which ones are more effective in increasing academic achievement in social studies course, makes it necessary to compare the effects of Jigsaw and Student Teams Achievement Divisions methods on academic achievement.

This research is limited with 48 6th students in Malatya province at 2014-2015 academic year, 6th grade social studies 6th unit 'Living Democracy' and 15 lesson hours. 
The aim of this study is to compare of the effect of Jigsaw and Student Teams Achievement Divisions methods based on cooperative learning to sixth grade students' academic achievement in social studies course.

In this study, pretest-posttest control ungrouped experimental model was used. Research, at 2014-2015 academic year to 48 6. grade students in Malatya province, has been made with the implementation the Jigsaw to Experimental I and Student Teams Achievement Divisions to Experimental II during 15 lesson.

Achievement Test used as data collection tool in this research, was implemented to 45 7th level students from different schools. Cronbach's alpha reliability value of Achievement Test that has 21 items is 0,897 .

Achievement Test used as data collection tool, applications to experimental groups before experiment and after experiment, Pretest that has equal variance was analyzed with parametric Independent Group T Test, Posttest was analyzed with non-parametric Mann Whitney U Test. According to research results, there was no significant difference between groups that implemented Jigsaw and Students Teams Achievement Divisions methods. 


\section{Giriş}

Eğitim sürecinde, bireyin öğrenmesi hedeflenmekte, bu amaçla eğitim uzmanları öğrenmeyi artıracak çeşitli yollar denemekte ve en iyi öğrenmeyi gerçekleştirecek yöntemlerin arayışı içine girmektedir. Artık günümüzde öğrencinin öğrenme sürecine aktif katılımının sağlanmasının zaruri olduğu aşikârdır. Bu amaçla Milli Eğitim Bakanlığı, sınıf içinde öğrenciyi aktif kılan bir anlayışla müfredatı yenileyerek okullarda yürürlüğe koymuştur. Milli Eğitim Bakanlığı, böylece öğretmenlerden derslerde daha farklı öğrenmeöğretme yöntemleri kullanmayı ve öğrenciyi merkeze alan yöntemler doğrultusunda eğitim vermelerini istemektedir. Yapılan araştırmalar göstermektedir ki, öğretmenler ne yazık ki istenilen düzeyde öğrencileri aktif kılamamakta ve farklı yol ve yöntemler kullanamamaktadır. Araştırmalara göre öğretmenlerin önündeki en önemli engel sürenin yetersizliği, öğrencilerin bireysel farklılıklarını dikkate alınamaması ve okullardaki altyapı yetersizliği olarak gösterilmektedir (Karacaoğlu \& Acar, 2010; Kuş \& Çelikkaya, 2010).

Araştırmalar, sosyal bilgiler öğretmenlerinin daha çok düz anlatım, soru-cevap, yazdırma ve beyin fırtınası yöntemlerini kullandığını (Çelikkaya \& Kuş, 2009: 755) göstermektedir. Maalesef mevcut durumda kullanılan yöntemler, öğrencilerin derse aktif şekilde katılımını sağlayamamakta ve öğrencinin derse karşı ilgisini düşürebilmektedir. Bu durum beraberinde akademik başarısızlığı getirebilmektedir.

Öğrencinin hem sosyalleşmesini hem de dersteki başarısını artıran öğretim yöntemlerinden birisi de işbirliğine dayalı öğrenmedir. İşbirliğine dayalı öğrenme 1980'lerden sonra hızla yayılmaya başlamış ve günümüzde eğitiminin diğer alanlarında olduğu gibi sosyal bilgiler eğitimi alanında da kullanılmaktadır.

\section{İşbirliğine Dayalı Öğrenme}

Uluslararası literatürde genellikle 'cooperative learning' olarak bilinen bu yöntem dilimize kubaşık, işbirlikli, işbirliğine dayalı öğrenme, işbirlikçi öğrenme (Doymuş, Şimşek \& Şimşek, 2005: 60) olarak aktarılmıştır.

İşbirliğine dayalı öğrenme, öğrencilerin oluşturulan gruplar içerisinde, birbirlerinin öğrenmelerinde aktif rol aldıkları süreç olarak değerlendirilmektedir. İşbirliğine dayalı öğrenmede öğrencilerin kendilerinin ve gruplarının öğrenmesi için çaba sarf etmesinden dolayı grup çalışmalarından ayrılmaktadır. Çünkü, işbirliğine dayalı öğrenmede grubun başarısı bireysel başarılardan daha üstündür. Ayrıca işbirliğine dayalı öğrenmede öğrenciler, öğrenme sürecinde eleştirme, açıklama, sorular sorma gibi yaşantıları elde ederek grup 
üyeleriyle etkileşimde bulunmaktadır. (Açıköz, 2002: 172). Bu öğrenmenin grup çalışmalarından farkı öğrencilerin hem kendilerinin hem de grup üyelerinin öğrenmelerinin en iyisi olması için uğraşmasıdır (Büyükkaragöz \& Çivi, 1997: 132).

İşbirliğine dayalı öğrenme modelinin faydalarını aşağıdaki gibi sıralamamız mümkündür (Büyükkaragöz \& Çivi, 1997: 134):

- Bilişsel ve duyuşsal öğrenmede diğer yöntemlere göre daha etkili sonuçlara ulaştırmaktadır.

- İşbirliğine dayalı öğrenmede öğrencilerin işbirliğiyle ilgili edindiği becerileri gelecekteki hayatında kullanma şansı bulmaktadır.

- İşbirliğine dayalı öğrenmede öğrenciler, ders esnasında dersle meşgul oldukları için sınıf içi disiplin problemleri en aza inmekte ve öğrencilerin ödev ve alıştırmalarını yapmalarını sağlamaktadır. Böylelikle öğretmenin işini kolaylaştırmaktadır.

- İşbirliğine dayalı öğrenmede öğretmen, yardım gerektiren öğrencilerle ilgilenme fırsatı bulmakta ve öğrenme güçlügü yaşanan noktalarda derhal müdahale etmektedir.

- İşbirliğine dayalı öğrenmede her öğrencinin öğrenmesi amaçlandığından öğrenme süreci bireyselleşmektedir.

- İşbirliğine dayalı öğrenme her türlü imkana sahip ortamda rahatlıkla uygulanma şansı bulduğundan kullanışı bir yöntemdir.

- İşbirliğine dayalı öğrenme öğretmene ve öğrenciye ek maliyet gerektirmediği için ekonomik bir yöntemdir.

İşbirliğine dayalı öğrenme modelinin faydalarını sayarken dikkat edilmesi gereken hususları da belirtmemiz gerekir (Büyükkaragöz \& Çivi, 1997: 135-136):

- Grupların büyüklüğü 2-6 kişi arasında olmalıdır.

- Gruplar heterojen yapıda olmalıdır. Yani, farklı yetenek, kişilik özellikleri, cinsiyet ve başarısı olanlar bir grupta toplanmalıdır.

- Öğretmen tarafından öğrencilere neler yapması gerektiği ile ilgili olarak bilgilendirme yapılmalıdır.

- Öğrenciler, bireysel olarak yarışmaktan ziyade grup olarak yarışmaları gerektiği için gruba ait olma duygusu benimsetilmelidir. 
- Öğretmen, işbirliğine dayalı öğrenme sürecinde gruplar arasında dolaşarak grup içindeki iletişime ve etkileşime yönelik rehberlikte bulunmalı, öğrencileri gözlemleyerek yardım gerektiği takdirde yardımda bulunmalıdır.

İşbirliğine dayalı öğrenme tek bir yöntemden ibaret olmayıp, her ders ve konu için değişebilen birçok yöntemleri bulunmaktadır (Efe, Hedevanlı, Ketani, Çakmak \& Aslan Efe, 2008: 21).

İşbirliğine dayalı öğrenme birçok yöntemi kendi içinde barındırmaktadır. Öğretmenin öğrencileri cinsiyet, başarı ve diğer özelliklerinden heterojen 4-6 kişilik gruplar oluşturması işbirliğine dayalı öğrenme yöntemlerinin kesişme noktasını oluşturmaktadır. İşbirliğine dayalı öğrenme modelinin tüm yöntemlerinde, grup içerisinde yer alan öğrencilerin akademik seviyeleri hem düşük, hem orta, hem de yüksek seviyededir (Slavin, 1981: 655).

\section{Ayrulıp Birleşme (jigsaw) Yöntemi}

Orijinal adı jigsaw olan ancak literatürümüzde Ayrılıp-Birleşme (Efe, Hedevanlı, Ketani, Çakmak \& Efe, 2008: 21), Birleştirme (Gömleksiz, 1993: 45; Açıkgöz, 2002: 210), Boz Yap (Büyükkaragöz \& Çivi, 1997: 138) ve Jigsaw (Şimşek, 2007: 18) olarak karşılaştığımız bu metot Eliot Aronson tarafından geliştirilmiştir (Açıgöz, 2002: 210). Ayrılıp Birleşme yöntemi, giriş, uzman araştırması, raporlaştırma ve tekrar biçimlendirme ve tamamlama ve değerlendirme aşamalarından oluşmaktadır. Giriş aşamasında öğretmen, sınıfı gruplara ayırarak işlenecek olan üniteyi öğrencilere tanıtıp konuları ve kaynakları vb. grup üyelerine paylaştırır. Öğretmen giriş kısmında sürecin nasıl işleyeceğiyle ilgili öğrencilere bilgilendirme yapar. Uzman araştırmasında her grupta aynı konuyu alan öğrenciler, bir araya getirilerek uzman gruplarını oluştururlar. Uzman gruplar, konularını etraflıca tartışıp araştırır ve çalışırlar. Uzman gruplarda öğrenciler konularını en iyi şekilde öğrenirler. Raporlaştırma ve yeniden biçimlendirme aşamasında uzman gruplarda konularını öğrenen öğrenciler baştaki gruplarına dönerek kendi konularını arkadaşlarını anlatarak onların da öğrenmelerini sağlarlar. Grup üyeleri sonunda bir rapor hazırlayarak çalışmalarını bitirirler. Tamamlama ve değerlendirme aşamasında ise öğrencilerin öğrendiklerini tamamlayıcı bir sunu veya etkinlik yapılarak değerlendirmeler yapılır (Şimşek, 2007: 18-19). Kısaca, önce gruplar oluşturulur, konular grup üyelerine paylaştırılır, her grubun aynı konuyu alan öğrencileri uzmanlık gruplarında uzmanlaşarak kendi gruplarında konuyu arkadaşlarına anlatır. En sonunda da öğrenciler konularla ilgili sınava girip değerlendirilirler (Slavin, 1981: 
656; Efe, Hedevanlı, Ketani, Çakmak \& Efe, 2008: 22; Açıkgöz, 2002: 210; Gömleksiz, 1993: 45, Büyükkaragöz \& Çivi, 1997: 138). Aranson'nun ayrılıp birleşme (jigsaw) tekniğinden uyarlanarak Jigsaw 2, Jigsaw 3, Jigsaw 4, Ters Jigsaw, Konu Jigsaw1 gibi isimlendirmelerle farklı yöntemler geliştirilmiştir. Şimşek (2007) bu yöntemlerin aşamalarını karşılaştırmalı olarak vermiştir.

\section{Öğrenci Takımlan Başan Grupları (ÖTBB) Yöntemi}

Robert Slavin tarafından geliştirilmiştir. Beş aşamadan oluşmaktadır. Bunlar; Öğretmen Sunumu, Grupların Belirlenmesi, Kısa Sınavlar, Bireysel Gelişim Puanları, Grupların Tanınmasıdır. Öğretmen tüm sınıfa işlenecek konuyu ayrıntılara inmeden genel olarak anlatır. Öğretmen öğrencileri bu aşamada konuya ilgilerini çeker ve yapacakları çalışmalar hakkında bilgi verir. Öğretmen sunum yaptıktan sonra işbirliğine dayalı öğrenme ilkelerine uygun olarak grupları belirleyerek çalışma kâğıtlarını öğrencilere verir. Gruplar kendi aralarında çalışma kağıtlarını yaparlar ve konuları kendi aralarında cevaplarlar. Öğrenmede eksiği olan öğrencilerin eksikliklerini gidermeye çalışırlar. Öğretmen tarafından öğrencilere kısa sınavlar uygulanır. Uygulanan kısa sınavların sonuçlarına göre öğrencilerin gelişim puanları belirlenir. Öğrencilerin gelişim puanlarına göre grupların puanları belirlenerek en fazla gelişim puanına sahip grup ödüllendirilir (Açıköz, 2002: 185-186; Efe, Hedevanll, Ketani, Çakmak \& Efe, 2008: 29).

İşbirlikli öğrenmenin uygulandığı sınıflarda gruplar oluşturulurken öncelikle öğrenciler akademik başarılarına göre sınıflandırılır ve oluşturulmak istenen grup sayısı kadar gruplandırılır. Oluşturulmuş olan gruplardan birer öğrenci seçilerek temel gruplar oluşturulur (Efe, Hedevanlı, Ketani, Çakmak \& Aslan Efe, 2008: 23-26).

İşbirliğine dayalı olarak çalışma insanlık tarihine kadar indirgenmişse de okullarda kullanılmaya başlaması 18.yüzyılların sonları ve 19. yüzyılın başlarına tekabül etmektedir. Özellikle 1980'li yıllarda popülerliğini artırmış ve 1990’lı yıllarda da ülkemizde eğitimin farklı kademelerinde ve derslerinde işbirliğine dayalı öğrenmeyle ilgili araştırmalar yapılmıştır. Şimşek (1990)'in de belirttiği gibi işbirliğine dayalı olarak oluşturulan grup çalışmaları, öğrenmede etkili olmaktadır. Johnson, Johnson ve Stanne (2000), işbirliğine dayalı öğrenme yöntemleriyle ilgili araştırmaların meta analizine bakarak, işbirliğine dayalı öğrenme yöntemlerinin etkisinin olduğunu belirtmiştir. Ülkemizde de Batd1 (2014), işbirliğine dayalı öğrenme yöntemlerinden Ayrılıp Birleşme (Jigsaw) yönteminin akademik 
başarıya etkisini araştıran araştırmaları meta analiz yöntemiyle inceleyerek, Ayrılıp Birleşme (Jigsaw) yönteminin akademik başarıyı artırmada etkili olduğunu dile getirmiştir.

Uluslararası düzeyde işbirliğine dayalı öğrenme, öğrencilerin sosyal bilgiler dersindeki akademik başarıyı artırdığı görülmektedir (Slavin, Chamberlain \& Hurley,2001), Adeyemi, 2008). Sosyal bilgiler dersinin öğretilmesinde işbirliğine dayalı öğretim yöntemlerinin etkililiği konusunda birçok araştırma yapılmıştır. Karaoğlu (1998), Delen (1998), Özkal (2000), Çetin (2002), Katılmış (2002), Kutay Atar (2003), Ersözlü (2004), Özkümüş (Yetkin) (2010), Göğebakan Yıldız (2012), Korkmaz Toklucu (2013) yaptıkları araştırmalarda, işbirliğine dayalı öğrenmenin sosyal bilgiler dersindeki akademik başarıyı artırdığını belirtmektedir. Kılıç (2006), Avşar ve Alkış (2007), Kuş ve Karatekin (2009), Oral (2000), Öner (2007), Meral ve Şimşek (2014) işbirliğine dayalı öğrenme yöntemlerinden olan Ayrılıp Birleşme (Jigsaw) yönteminin ve Kaşaveklioğlu (2013) ve Küçükilhan (2013) işbirliğine dayalı öğrenme yöntemlerinden Öğrenci Takımları Başarı Bölümleri (ÖTBB) yönteminin sosyal bilgiler dersinde başarıyı artırdığını dile getirmektedirler. İlgili alanyazında yapılan araştırmalara bakıldığında genelde sadece bir işbirliğine dayalı öğrenme yönteminin sosyal bilgiler dersindeki akademik başarısına etkisi incelenmiştir. İşbirliğine dayalı öğrenme yöntemlerinin kendi içinde hangisinin daha etkili olduğuna yönelik olarak bir araştırmanın eksikliği literatürde göze çarpmaktadır. Bu araştırma literatürdeki bu eksikliği gidermede yardımcı olacağı için önem arz etmektedir.

Ayrıca sosyal bilgiler dersinde işbirliğine dayalı öğrenme yöntemine göre dersi işlemenin kavram öğretiminde (Çayc1, Demir, Başaran \& Demir, 2007) ve problem çözme başarısında (Özdemir, 2005) etki olduğu görülmektedir. Sosyal bilgiler dersinin öğretilmesinde işbirliğine dayalı öğretimin öğrencilerin problem çözme becerilerini geliştirmede etkili olduğunu öğretmen, müfettiş, uzman ve öğrenciler de belirtmektedir (Akyürek Tay, 2002).

Yapılan araştırmalar ışığında sosyal bilgiler dersinde işbirliğine dayalı diğer yöntemler gibi Ayrılıp Birleşme ve Öğrenci Takımları Başarı Bölümleri yöntemlerinin de sosyal bilgiler dersinde bakanlığın belirlediği mevcut öğretime göre başarılı olduğu söylenebilir.

İşbirliğine dayalı öğrenmeye göre düzenlenmiş bir sosyal bilgiler dersinin bakanlığın belirlediği mevcut öğretime göre başarılı olduğu araştırmalarla sabit olmakla birlikte, işbirliğine dayalı öğrenme yöntemlerinin hangilerinin daha etkili olduğu konusundaki 
araştırmalar maalesef yeterli değildir. Gelen (2001), işbirliğine dayalı öğrenme yöntemlerinden Öğrenci Takımları Başarı Bölümleri ile Ayrılıp Birleşme II tekniklerinin 4. sınıf sosyal bilgiler dersi akademik başarısına etkisini karşılaştırmış ve Sezer ve Tokcan (2003: 231)’ın belirttiğine göre, Öğrenci Takımları Başarı Bölümleri yönteminin daha etkili olduğu görülmüştür. Meral ve Şimşek (2014), işbirliğine dayalı öğrenme yöntemlerinden Ayrılıp Birleşme (Jigsaw) ve Grup Araştırması tekniklerinin kendi aralarında sosyal bilgiler dersindeki akademik başarıyı artırmada bir farklarının olmadığını sonucuna ulaşmıştır.

Sosyal bilgiler dersindeki akademik başarıyı artırmada işbirliğine dayalı öğrenme yöntemlerinin hangilerinin daha etkili olduğu konusundaki araştırmaların yetersizliği, işbirliğine dayalı öğrenme yöntemlerinden olan Ayrılıp Birleşme ve Öğrenci Takımları Başarı Bölümleri yöntemlerinin sosyal bilgiler akademik başarısına etkisinin karşılaştırılması ihtiyacını doğurmaktadır.

\section{Araştırmanın Amacı}

$\mathrm{Bu}$ araştırmanın amacı, işbirliğine dayalı öğretim yöntemlerinden olan Ayrılıp Birleşme (Jigsaw) ve Öğrenci Takımları Başarı Bölümleri (ÖTBB)'nin sosyal bilgiler dersindeki akademik başarıya etkisini karşılaştırmaktır.

\section{YÖNTEM}

\section{Araştırma Modeli}

$\mathrm{Bu}$ araştırma nicel modele göre yapılmıştır. Nicel araştırma modelleri, sayısal verilerin istatistiksel yöntemlerle analiz edildiği araştırmalar olup, ulaşılmak istenen sonucun ne kadar ve ne ölçüde gibi niceliksel sorulara cevap arandığı aranmaktadır. Nicel araştırmalarda ölçümlerin tekrarlanabilmesi bu araştırmaların değerli kılmaktadır (Gürbüz \& Şahin, 2016: 105).

$\mathrm{Bu}$ araştırmada eşitlenmemiş gruplar ön test-son test yarı deneysel desen tercih edilmiştir. Eşitlenmemiş karşılaştırma gruplu desen de denilen bu desende deney gruplarında, deney öncesi ve deney sonrası ölçümlerin benzer ve farklılıklarına bakılır (Gliner, Morgen \& Leech, 2015: 59). Deney öncesi grup ölçümlerinde farklılıkların olmaması, sonucun doğru okunmasını kolaylaştırmaktadır. Yani, ön test ve son testin bulunduğu deneysel çalışmalarda bir değerlendirme yapabilmek için grupların ön test puanları karşılaştırılır ve ön test puanları arasında anlamlı fark yoksa grupların son test puanları karşılaştırılarak sonuç hakkında bir değerlendirme yapılır (Karasar, 2012: 97). 


\section{Çalışma Grubu}

Araştırmada kullanılan çalışma grubu, 'kolay ulaşılabilir durum örneklemesi' yoluyla elde edilmiştir. Seçilen örneklem de denilen bu örneklem yönteminde araştırmacının evrenden yakın ve kolay ulaşabileceği katılımcıları örneklem olarak alması işlemidir (Gliner, Morgen \& Leech, 2015: 117-125).

$\mathrm{Bu}$ araştırmada kullanılan çalışma grubunu, Malatya ilinde öğrenim gören 48 altıncı sınıf öğrencileri oluşturmaktadır. Deney I grubunda 22, Deney II grubunda ise 26 öğrenci bulunmaktadır. Araştırma öncesinde her iki grubun da 2014-2015 eğitim öğretim yılı birinci dönemindeki sosyal bilgiler notlarına göre aralarında anlamlı bir fark olup olmadığını öğrenmek amacıyla gruplar arasında bağımsız gruplar $t$ testi yapılmıştır. Her iki grubun birinci dönem sosyal bilgiler puanları (Deney I $\cdot$ : 57; Deney II $\cdot:$ 64) arasındaki $\mathrm{t}$ testi sonucuna göre anlamlı bir farkın olmadığ1 görülmüştür, $\mathrm{t}_{46}=-1,59, \mathrm{p}=0.12$. Sonuç olarak, öğrenci başarısı bakımından birbirine eşdeğer iki grubun, çalışma grubu olmasına karar verilmiştir. Deney gruplarına hangi yöntemin uygulanacağı konusunda yansız davranılmıştır.

\section{Veri Toplama Teknikleri}

Araştırmada kullanılan verileri toplamak için Başarı Testi'nden faydalanılmıştır.

\section{Başarı Testi}

Altıncı sınıf sosyal bilgiler dersi ünitesinin kazanımlarıyla ilgili olarak her kazanımdan eşit derecede olacak şekilde 5 kazanımdan 25 dört seçenekli çoktan seçmeli test hazırlanmıştır. Başarı testi hazırlanırken müfredattaki kazanımlar dikkate alınarak, 6. sınıf ders kitaplarından da yararlanılarak özgün sorular hazırlanmıştır. Özgün hazırlanan başarı testi önce sosyal bilgiler öğretmenlerinin görüşüne, daha sonra da uzman görüşüne sunularak öneriler doğrultusunda düzeltmeler yapıldıktan sonra, bir önceki sene bu konuyu gören farklı okullardaki kırk beş yedinci sınıf öğrencisine sınıf ortamında uygulanmıştır. Ön uygulama sonuçlarına göre test maddelerinin güçlük ve ayırt edicilik indekslerine bakıldıktan sonra testin güvenirliği hesaplanmıştır. Test maddelerinin güçlük ve ayırıcılık indekslerine bakmak için ön uygulamaya dahil edilen kırk beş kişi, başarı testine göre sıralanarak en başarılı on beş öğrenci (üst) ve en başarısız on beş öğrenci (alt) olmak üzere alt ve üst gruplara ayrıştırılmıştır. Daha sonra başarı testinin maddelerinin güçlük düzeylerine bakmak için kaynaklarda belirtilen şu formül uygulanmıştır (Özçelik, 1981: 146; Yılmaz, 1996: 213; Yıldırım, Tarihsiz: 148; Tekin, 2009: 247; Erkuş, 2006: 41; Turgut, 1977: 252). 
Madde Güçlüğü (p)= Maddeyi üst ve alt grupta doğru cevaplayanların sayısı/Üst ve alt grupların tümü

$\mathrm{Bu}$ formül sonucuna göre madde güçlükleri 0-1 arasında değişen rakamları almaktadır. 0 rakamından 1 rakamına doğru maddenin güçlük değerleri düşmektedir. Bir ölçme aracında madde güçlüklerinin değerleri 0,20-0,80 arasında olmasının gerekmesi (Erkuş, 2006: 41) nedeniyle, başarı testinin maddelerinin güçlük değerleri 0,20'den düşük olanlar ve 0,80'den yüksek olanlar çıkarılmıştır.

Maddenin ayırıcılık gücüne (d) ise, maddeyi alt grupta doğru cevaplayanların sayısını üst grupta doğru cevaplayanların sayısından çıkarıp üst veya alt grup sayısından birisine bölünmesiyle elde edilen değer esas alınarak (Tekin, 2009: 249; Erkuş, 2006: 44; Turgut, 1977: 253) bulunmuştur. Buna göre madde ayırıcılık gücü 0-1 arasında değişen değerler almaktadır. 0 rakamından 1 rakamına doğru maddenin ayırıcılık gücü artmaktadır. Genellikle madde ayrıcılık değeri 0,30 ve yüksek olan değerler ayırt edici maddeler kabul edildiğinden (Erkuş, 2006: 44) başarı testinin madde ayırıcılık değerlerinin 0,30'dan düşük olduğu maddeler testten çıkarılmıştır. Madde güçlüğü $0,20^{\prime}$ den düşük ve $0,80^{\prime}$ den yüksek olanlar ile madde ayırıcılık indeksleri 0,30' dan düşük olan test maddeleri çıkarıldıktan sonra kalan 21 maddelik Başarı Testi'nin Cronbach's Alfa güvenirlik değeri 0,897 olarak bulunmuştur. Bulunmuş olan güvenirlik değerinden Başarı Testi'nin güvenilir nitelikte olduğu görülmektedir.

\section{Araştırmanın Uygulanması}

Araştırma 2016-2017 eğitim öğretim yılında Malatya ilinde 6. sinıflarda, Sosyal Bilgiler Dersi 6. Ünite Demokrasinin Serüveni ünitesinin 10 Nisan 2017 ile 21 Mayıs 2017 tarihleri arasında, sosyal bilgiler ders kitabında önerilen 15 saatlik zamanda sınıf ortamında uygulanmıştır. Uygulama öncesinde her iki deney grubunun 2016-2017 eğitim öğretim yılı birinci dönemindeki sosyal bilgiler notları dikkate alınarak gruplar oluşturulmuş ve Deney I grubuna Ayrılıp Birleşme (Jigsaw), Deney II grubuna Öğrenci Takımları Başarı Bölümleri (ÖTBB) yöntemleri uygulanmıştır.

\section{Grupların Oluşturulması}

Deney I ve Deney II gruplarındaki sınıf mevcudu ve işlenecek ünitedeki konu dikkate alınarak öncelikle oluşturulacak grup sayısı belirlenmiştir. 6. sınıf Demokrasinin Serüveni ünitesinde beş konu olduğundan dolayı gruplarda en az beş öğrencinin olmasına dikkat edilmiştir. Deney I grubunda 22 öğrenci olduğu için beşerli 4 grup, Deney II grubunda 26 
öğrenci olduğu için beşerli 5 grubun oluşturulmasına karar verilmiştir. Deney I ve Deney II gruplarının 2016-2017 I. dönemindeki sosyal bilgiler dersi dönem puanlarına göre başarı sıralaması yapılarak Deney I grubunda 4, Deney II grubunda da 5 gruba ayrılmıştır. Başarı sıralamasına göre ayrılan gruplardan birer öğrenci seçilerek asıl gruplar oluşturulmuştur. Deney I grubundaki fazlalık 2 öğrenci ve Deney II grubundaki fazlalık 1 öğrenci rastgele bir gruba dahil edilmiştir. Deney I ve Deney II gruplarındaki gruplandırmalarda, grupların başarı ve cinsiyet özellikleri bakımından heterojen olmasına özellikle dikkat edilmiştir.

\section{Öğretim Yöntemlerinin Uygulanması}

Araştırmada işbirliğine dayalı öğrenme yöntemlerinden Ayrılıp Birleşme (Jigsaw) ve Öğrenci Takımları Başarı Bölümleri (ÖTBB)’ın öğrenci başarısında etkisi karşılaştırıldığından Deney I ve Deney II gruplarının hangisine hangi yöntemin uygulanacağı konusunda rastgele seçim yapılmıştır. Buna göre Deney I grubunda Ayırıp Birleşme (Jigsaw), Deney II grubunda Öğrenci Takımları Başarı Bölümleri (ÖTBB) yönteminin uygulanmasına karar verilmiştir.

$\mathrm{Bu}$ araştırmada Deney I grubuna işbirliğine dayalı öğrenme yöntemlerinden Ayrılıp Birleşme (Jigsaw), devlet okuluna ait bir derslik ortamında öğrenci sıralarının birleştirilmesiyle oluşturulmuş gruplar yoluyla uygulanmıştır. Dersler haftada 3 saat olmak üzere toplam 15 saatte uygulanmıştır. Hafta içinde tatil olan veya başka bir etkinlikten dolayı işlenemeyen dersler daha sonraki haftalarda haftalık ders saatine uygun olarak telafi edilmiştir.

Deney II grubuna ise işbirliğine dayalı öğrenme yöntemlerinden Öğrenci Takımları Başarı Bölümleri (ÖTBB), devlet okuluna ait bir derslik ortamında öğrenci sıralarının birleştirilmesiyle oluşturulmuş gruplar üzerine uygulanmıştır. Dersler haftada 3 saatten toplam 15 ders saatinde tamamlanmıştır. Hafta içi sosyal bilgiler dersinin işlenemediği durumlarda, bir sonraki hafta sosyal bilgiler dersinde konu telafi edilmiştir.

\section{Ayrnlıp birleşme (jigsaw) yönteminin uygulanması}

Öğrencilere bir hafta önceden işlenecek konu ve yöntem hakkında bilgilendirme yapılmıştır. Öğretmen tarafından oluşturulan gruplar öğrencilere duyurulduktan sonra memnun olmayan öğrencinin olup olmadı̆̆ı gözlemlenmiştir. Oluşturulan gruplardan her grubun memnun olduğu gözlenince, çalışmaları için sınıfta nasıl oturmaları gerektiği anlatılmıştır. Belirlenen grupların ne yapmaları gerektiği ve grup olarak çalışacaklarında uyması gereken kuralların ne olduğu hatırlatılmıştır. Çalışma sırasında birbirlerine karşı nazik olmaları ve dinlemeleri gerektiği, grup içinde bir sorularının olduğu zaman önce grup 
arkadaşlarına sormaları gerektiği gibi kurallar hatırlatılmıştır. Öğrencilerin grup üyeleriyle konuşmalarına izin verilerek gruplarına bir ad vermeleri ve grup üyelerinin bir konu seçmeleri istenmiştir. Öğrenciler, gruplarına bir ad koyduktan sonra konuları paylaşmış, yardım isteyen gruplara bu aşamada öğretmen tarafından yardımda bulunulmuş ve konularını çalışmaları için kendilerine bir hafta süre verilmiştir. Daha sonra her gruptan aynı konuyu alan öğrenciler uzman grupları oluşturarak konuları birbirlerine anlatmışlar ve raporlaştırmışlardır. Kendi konularında uzman olan öğrenciler asıl gruplarına dönerek konuları arkadaşlarına anlatmışlar ve soru cevap ve çeşitli etkinliklerle konuyu grup üyelerinin daha iyi öğrenmesini sağlamışlardır. Yöntemin son aşamasında, grup olarak hazırlanan raporlardan rastgele seçilmiş bir tanesi tüm sınıfa sunulmuş ve genel değerlendirme sonrası başarılı olan grup başarı belgesi ve notla ödüllendirilmiştir.

\section{Öğrenci takımları başarı bölümleri (ÖTBB) yönteminin uygulanması}

Öğrencilere ilk olarak işlenecek ünite ve öğretim yöntemi hakkında bilgilendirme yapılarak öğretmen tarafından oluşturulan gruplar, öğrencilere duyurulmuştur. Öğrencilerin gruplarından memnuniyetlerine bakıldığında iki grupta birbiriyle konuşmayan öğrencilerin olduğu gözlenince hemen başarı ve cinsiyet faktörleri dikkate alınarak başka gruplar arasında değişim yapılarak, öğrencilerin kendi gruplarından memnun olmaları sağlanmıştır. Daha sonra sınıf içerisinde grupların nasıl oturmaları gerektiği, grup üyeleriyle nasıl iletişim kurmaları gerektiği konusunda bilgilendirme yapılmıştır. Öğrenciler izlenecek süreç hakkında bilgi verildikten sonra, öğrenci takımlarına göre hazırlanan gelişim çizelgesi herkesin görebileceği yere asılmıştır. Gelişim puanı çizelgesinde 2016-2017 eğitim öğretim puanı temel puan olarak kabul edilmiş ve süreç içinde 3 ara sınavın yapılmasına karar verilmiştir. Gelişim puanının hesaplanmasında temel puandan 5 puan eksik ve daha az olana 0 puan, temel puandan 4 puan eksik ve 4 puan fazlaya kadar 1 puan, temel puandan 5 puan ve 9 puan arasında yüksek olana 2 puan ve temel puandan 10 ve fazla olana 3 puan verilmesi esas alınmıştır. Her konunun başında öğretmen, konuyu genel olarak sınıfa sunduktan sonra öğrencilere ek çalışma kağıtları dağıtarak birlikte çalışmalarını sağlamıştır. Öğrencilerin farklı kaynaklardan çalışabilecekleri ve arkadaşlarıyla kendi hazırladıkları veya temin ettikleri etkinliklerle de konuyu çalışabilecekleri belirtilmiştir. Süreç içinde uygulanacak olan 3 ara sinavın 2'si, konuyu bir önceki senede gören 7. sinıflar üzerinde uygulanarak madde güçlük ve ayırt edicilik değerlerinin bulunup, madde güçlük değerlerinde 0,20'nin altında ve 0,80'nin üstünde olan maddeler ve ayırt edicilik 
değerlerinde 0,30'un altında olan maddeler çıkarılmasıyla ara sınav maddeleri oluşturulmuştur. Güçlük ve ayrıcılık indekslerine bakıldıktan sonra geriye kalan 7 maddelik I. ara sınavın güvenirlik katsayısı 0,722 ve 10 maddelik II. ara sınavın güvenirlik katsayısı 0,810 olarak bulunmuş ve her iki ara sınav maddeleri güvenli bulunduğu için uygulanmasına karar verilmiştir. İlk iki konu işlendikten sonra birinci ara sınav, daha sonraki iki konu işlendikten sonra da ikinci ara sınav yapılmıştır. Süreç sonunda yapılan son test de üçüncü sınav kabul edilerek her grubun ilerleme puanına bakılmıştır. Süreç sonunda birinci olan grup başarı belgesi ve puanla ödüllendirilmiştir.

\section{Verilerin analizi}

Sınıf ortamında bizzat araştırmacının gözetiminde işbirliğine dayalı öğrenme yöntemlerinin uygulanmasından önce ve uygulamadan sonra uygulanan başarı testi puanları bilgisayar ortamı üzerinde istatistik program kullanılarak analiz edilmiştir. SPSS 21. versiyon kullanılarak Deney I ve Deney II grubunun birbirleri arasında deney öncesi ve sonrası anlamlı bir farkın olup olmadığını belirlemek amacıyla ve hangi testin kullanılacağına karar vermek için grupların Ön Test ve Son Test puanlarının dağılımına bakılmıştır. Çünkü grupların testlerden aldıkları puanlarının dağılımı kullanılacak olan testi etkilemektedir. Bağımsız iki grup arasındaki farkı ortaya koyabilmek ve paremetrik testlerden bağımsız gruplar $t$ testi uygulayabilmek için verilerin dağılımının normal olması gerekirken, parametrik olmayan (nonparametrik) testlerden Mann Whitney U Testi uygulayabilmek için verilerin normal olması şart değildir (Baştürk, 2011: 99). Bu nedenle verileri analiz etmeden önce, öncelikle verilerin Normallik Testine bakmak gerekmektedir. $\mathrm{Bu}$ araştırmada kullanılan gruplara uygulanan Ön Test ve Son Test puanlarının Normallik Testi Sonuçları aşağıdaki Tablo 1'de gösterilmiştir.

Tablo 1. Ön Test ve Son Test Puanlarının Normallik Testi Sonuçları

\begin{tabular}{lllll}
\hline Test & & İstatistik & Standart Hata & $\mathrm{p}$ (Shapiro-Wilk) \\
\hline \multirow{2}{*}{ Ön Test } & Çarpıklık (Skewness) & 0,06 & 0,34 & \multirow{2}{*}{0.31} \\
\cline { 2 - 5 } & Basıklık (Kurtosis) & $-0,46$ & 0,67 & 0.03 \\
\hline \multirow{2}{*}{ Son Test } & Çarpıklık (Skewness) & $-0,40$ & 0,34 & \multirow{2}{*}{ Basılık (Kurtosis) } \\
\cline { 2 - 5 } & Basık & $-0,92$ & 0,67 & \\
\hline
\end{tabular}

Tablo 1'e bakıldı ̆̆ı zaman Ön Test puanlarının dağılımının normal olduğu ( $p>0.05)$ ve Son Test puanlarının dağılımının normal olmadığı $(\mathrm{p}<0.05)$ görülmektedir. Bu nedenle Deney I ve Deney II gruplarının Ön Test puanlarına göre karşılaştırmak için Bağımsız Grup t Testi'ne başvurulurken, Deney I ve Deney II gruplarının Son Test puanlarına göre 
karşılaştırmak için Mann Whitney U Testi'ne başvurulmuştur. Yapılan testler sonucunda gruplar arasında farkın $0.05^{\prime}$ in altında olanlar, anlamlı olarak kabul edilmiştir.

\section{BULGULAR}

Araştırmaya konu olan işbirliğine dayalı öğrenme yöntemlerinden Ayrılıp Birleşme yönteminin uygulandığı Deney I grubunun ve Öğrenci Takımları Başarı Bölümleri yönteminin kullanıldığı Deney II grubunun Ön Test ve Son Test sonuçlarına göre betimsel istatistikleri ve bağımsız grup t testi sonuçları aşağıda alt başlıklar halinde sunulmuştur.

Deney gruplarmm ön test sonuçlarma göre betimsel istatistikleri ve t testi sonuçları

$\mathrm{Bu}$ araştırmada deney öncesi Deney I ve Deney II gruplarına uygulanan Ön Test puanlarının karşılaştırılması için grupların betimsel istatistikleriyle birlikte bağımsız grup t testi sonuçları aşağıdaki tabloda gösterilmiştir.

Tablo 2. Deney Gruplarının Ön Test Sonuçlarına Göre -Betimsel İstatistikleri ve Bapımsız Grup t Testi Sonuçları

\begin{tabular}{lllllll}
\hline Deney Grupları & $\mathbf{n}$ & $\cdot$ & SS & $\mathbf{t}$ & df & p \\
\hline Deney Grubu I & 22 & 8,91 & 4,67 & & & \\
\hline Deney Grubu II & 26 & 11,04 & 3,73 & & & \\
\hline${ }^{*} \mathrm{p}>0.05$ & & & & & & \\
\hline
\end{tabular}

Tablo 2'de görüldüğü üzere Deney I ve Deney II gruplarının ön test sonuçlarına göre aralarında anlamlı bir farkın olup olmadığını öğrenmek amacıyla bağımsız gruplar $\mathrm{t}$ testi yapılmıştır. Test sonucuna göre, Deney I $(\cdot=8,91)$ ve Deney II $(\cdot=11,04)$ gruplarının ön test puan ortalamaları arasında anlamlı bir fark yoktur, $\mathrm{t}_{46}=-1,76 ; \mathrm{p}=0.90$

Karasar $(2012,97)^{\prime}$ ın da belirttiği gibi ön test sonucuna göre gruplar arasındaki farkın anlamsız çıkması, grup karşılaştırmalarının doğru yorumlanmasını sağlamaktadır. Bu açıdan bu araştırmadaki grupların ön test sonuçlarına göre birbirlerine benzer düzeyde olduklarını göstermektedir. Diğer bir deyişle, deney öncesi grupların seviyeleri birbirine yakındır.

Deney gruplarmın son test sonuçlarına göre betimsel istatistikleri ve Mann Whitney U Testi sonuçları

Deney I ve Deney II grubuna işbirliğine dayalı öğrenme yöntemlerinden Ayrılıp Birleşme ve Öğrenci Takımları Başarı Bölümleri yöntemlerinin uygulanmasından sonra gruplara yapılan Son Test sonuçlarına göre, gruplar arasında karşılaştırma yapmak için gerekli istatistiksel bilgiler ve Mann Whitney U Testi sonuçları aşağıdaki tabloda verilmiştir. 
Tablo 3. Deney Gruplarının Son Test Sonuçlarına Göre Betimsel İstatistikleri ve Mann Whitney U Testi Sonuçları

\begin{tabular}{ccccclcll}
\hline Deney Grupları & N & & SS & Sira Toplamı & $\begin{array}{l}\text { Sira } \\
\text { Ortalaması }\end{array}$ & U & Z & p \\
\hline Deney Grubu I & 22 & 11,23 & 5,94 & 459,5 & 20,89 & 206,5 & $-1,65$ & $0.10^{*}$ \\
\hline Deney Grubu II & 26 & 14,08 & 4,85 & 716,5 & 27,56 & 206 &
\end{tabular}

Tablo 3'te, Deney Grubu I ve Deney Grubu II gruplarının son test puanları açısından aralarında anlamlın bir farkın olup olmadığını öğrenmek amacıyla yapılan Mann Whitney U Testi sonuçları görülmektedir. Mann Whitney U Testi sonucuna göre Deney I grubu ( · $=11,23, \mathrm{n}=22)$ ile Deney II grubu $(\cdot=14,08, \mathrm{n}=26)$ arasında son test puanları bakımından anlamlı bir fark bulunmamaktadır, $U=206,5 ; Z=-1,65 ; p=0.10$. Araştırmanın bu bulgusu, Gelen (2001)'nin bulgularıyla zıt düşerken, Meral ve Şimşek (2014)'in bulgularını desteklemektedir.

\section{SONUÇ ve TARTIŞMA}

İşbirliğine dayalı öğrenme yöntemlerinden Ayrılıp Birleşme ve Öğrenci Takımları Başarı Bölümleri yöntemlerinin 6. sınıf sosyal bilgiler dersindeki akademik başarıya olan etkisinin karşılaştırılmasının amaçlandığı bu araştırmada elde edilen sonuçlar aşağıda belirtilmiştir.

Deney I grubuna uygulanan işbirliğine dayalı Ayrılıp Birleşme (Jigsaw) yöntemiyle, Deney II grubuna uygulanan Öğrenci Takımları Başarı Bölümleri (ÖTBB) yönteminden akademik başarıyı artırma yönünden aralarında istatistiksel olarak anlamlı bir fark bulunmamaktadır.

$\mathrm{Bu}$ araştırma sonucunun diğer araştırma sonuçlarıyla kıyaslandığında, Gelen (2001)'in Ayrılıp Birleşme II ve Öğrenci Takımları Başarı Bölümleri yöntemlerini 4. sınıflara uygulayarak bu yöntemlerin sosyal bilgiler dersindeki akademik başarıya olan etkisini karşılaştırarak Öğrenci Takımları Başarı Bölümleri yönteminin daha etkili olduğunu belirten araştırma sonucuyla çelişmektedir. Gelen (2001)'in araştırmasında kullanılan yöntemler bu araştırmanın yapıldığı 2017 yılından bir hayli önceki zamanda ve 4. sınıflarda uygulanmıştır. İki araştırma arasında hem zaman hem de öğrenci seviyesi farkı vardır. Bu nedenle iki araştırma arasında farklı sonuçların çıkması gayet muhtemeldir. Son zamanlardaki teknoloji ve eğitim dünyasındaki gelişmeler, kaynakların kolay ulaşılabilirliği, öğrencilerin hazır bulunuşluklarının önceki dönemlere göre yüksek olması, eğitim programlarının yenilenmesiyle öğrencilerin eğitim sürecinde daha aktif olması, öğrencilere uygulanan 
öğretim yöntemlerinin etkililiğini de etkileyebilmektedir. Bu nedenle iki araştırma arasındaki farklılığın nedenini doğru ortaya koyabilmek için başka araştırmalara ihtiyaç duyulmaktadır.

Meral ve Şimşek (2014)'in işbirliğine dayalı öğrenme yöntemlerinden Ayrılıp Birleşme ve Grup Araştırması yöntemlerini 6. sınıflara uygulayarak iki yöntemin sosyal bilgiler dersindeki akademik başarıyı artırmada aralarında bir farkın olmadığını belirten sonucu, bu araştırma sonucuyla benzerlik taşımaktadır.

Bunlardan hareketle, işbirliğine dayalı öğrenme yöntemlerinden ikisi olan Ayrılıp Birleşme ve Öğrenci Takımları Başarı Bölümleri yöntemleri sosyal bilgiler derslerinde akademik başarıyı artırmada aralarında bir farklılığın bulunmaması, işbirliğine dayalı her iki yöntemin de sosyal bilgiler akademik başarıyı artırmada birbirine eşit etkide olduklarını göstermektedir. Yani her iki yöntemin sosyal bilgiler akademik başarısını artırmada birbirlerinden bir üstünlükleri yoktur. $\mathrm{Bu}$ sonucun böyle olmasında, günümüzde öğrencilerin bilgi kaynaklarına erişmedeki kolaylıkları, müfredatın yapılandırmacı anlayış doğrultusunda yenilenmesiyle öğrencilerin derslerde daha aktif olmalarının ektileri olabilir. Öğrencilerin bilgi kaynaklarını kolayca erişmesi sayesinde konulara daha iyi hazırlanma imkanı bulurken, derslerde aktif olması da diğer aktif öğrenme yöntemlerinin uygulanmasinda kolaylıklar sunmaktadır.

\section{Öneriler}

İşbirliğine dayalı öğrenme yöntemlerinden Ayrılıp Birleşme ve Öğrenci Takımları Başarı Bölümleri yöntemleri, sosyal bilgiler derslerindeki akademik başarıya etkilerinde bir farklılık bulunmadığından her iki yöntem de sosyal bilgiler öğretmenleri tarafından derslerde kullanılabilir.

$\mathrm{Bu}$ araştırmada, işbirliğine dayalı öğrenme modelinin sadece Ayrılıp Birleşme ve Öğrenci Takımları Başarı Bölümleri yöntemlerinin sosyal bilgiler dersindeki akademik başarıya etkisi araştırılmıştır. Bu nedenle, işbirliğine dayalı Ayrılıp Birleşme ve Öğrenci Takımları Başarı Bölümleri yöntemleri haricindeki diğer işbirliğine dayalı öğrenme yöntemlerinin sosyal bilgiler dersi akademik başarısına etkisinin karşılaştırılması başka araştırmalarda yapılabilir.

\section{KAYNAKÇA}

Açıkgöz, K. Ü. (2002). Aktiföğrenme. İzmir: Eğitim Dünyası Yayınları. 
Adeyemi, B. A. (2008). Effects of cooperative learning and problem-solving strategies on junior secondary school students' achievement in social studies. Electronic Journal of Research in Educational Psychology. 6 (3).691-708.

Akyürek Tay, B. (2002). İlköğretim 4. ve 5. sinıf sosyal bilgiler dersinde öğrencilerin problem çözme becerilerini geliştirmede işbirliğine dayah öğrenmenin etkisi konusunda öğretmen, müfettiş ve uzman görüşleri. Yayınlanmamış Yüksek Lisans Tezi. Hacettepe Üniversitesi Sosyal Bilimler Enstitüsü.

Avşar, Z. ve Alkış, S. (2007). İşbirlikli öğrenme yöntemi "Birleştirme I" tekniğinin sosyal bilgiler derslerinde öğrenci başarısına etkisi. İlköğretim Online. 6(2), 197-203.

Baştürk, R. (2011). Bütün yönleriyle SPSS örnekli nonparametrik istatistiksel yöntemler. 2. Bask1. Ankara: Anı Yayıncılık.

Batdı, V. (2014). Jigsaw tekniğinin öğrencilerin akademik başarılarına etkisinin meta-analiz yöntemiyle incelenmesi. EKEV Akademi Dergisi. 58, 699-714.

Büyükkaragöz, S. ve Çivi, C. (1997). Genel öğretim metotları. İstanbul: Öz Eğitim Yayınları.

Çaycı, B., Demir, M.K., Başaran, M. \& Demir, M. (2007). Sosyal bilgiler dersinde işbirliğine dayalı öğrenme ile kavram öğretimi. Kastamonu Eğitim Dergisi. Cilt:15, No:2, 619-630.

Çelikkaya, T. \& Kuş, Z. (2009). Sosyal bilgiler öğretmenlerinin kullandıkları yöntem ve teknikler, Uludă̆ Üniversitesi Eğitim Fakültesi Dergisi, Sayı: XXII (2). 741-758.

Çetin, B. (2002). Sosyal bilgiler öğretiminde işbirliğine dayalı öğrenme yönteminin ilköğretim 4. sınıf öğrencilerinin bilişsel erişi düzeylerine etkisi. Yayınlanmamış Yüksek Lisans Tezi. Marmara Üniversitesi Eğitim Bilimleri Enstitüsü.

Delen, H. (1998). Temel eğitim beşinci sınıf sosyal bilgiler dersinde kubaşık öğrenme yönteminin akademik başarıya etkisi. Yayınlanmamış Yüksek Lisans Tezi. Çukurova Üniversitesi Sosyal Bilimler Enstitüsü.

Doymuş, K., Şimşek, Ü. \& Şimşek, U. (2005). İşbirlikçi öğrenme üzerine derleme: I. işbirlikçi öğrenme yöntemi ve yöntemle ilgili çalışmalar. Erzincan Eğitim Fakültesi Dergisi. Cilt: (7). Sayı: (1).

Efe, R., Hedevanlı, M., Ketani, Ş., Çakmak, Ö. \& Aslan Efe, H. (2008). İşbirlikli öğrenme teori ve uygulama. Ankara: Eflatun Yayınevi.

Erkuş, A. (2006). Sinıf öğretmenleri için ölçme ve değgerlendirme kavramlar ve uygulamalar. Ankara: Ekinoks Eğitim Danışmanlık Hiz. ve Bas. Yay. Dağ. San. ve Tic. Ltd. Şti.

Ersözlü, Z. N. (2004). İlköğretim 5. sınıf sosyal bilgiler dersinde işbirliğ̈ine dayalı öğrenmenin öğrencilerin akademik başarılarına ve hatırda tutma düzeylerine etkisi (Bilecik-Bozüyük ilçesinde bir araştırma). Yayınlanmamış Yüksek Lisans Tezi. Sakarya Üniversitesi Sosyal Bilimler Enstitüsü.

Gelen, İ. (2001). Kubaşık öğrenme tekniklerinden öğrenci takımları başarı bölümleri ve birleştirme II tekniğinin 4. sınıf öğrencilerinin sosyal bilgiler dersindeki akademik başarıya etkisinin karşılaştırılması. Eurasian Journal of Educational Research. 5.

Gliner, J. A., Morgan, G. A. \& Leech, N. L. (2015). Uygulamada araştırma yöntemleri Desen ve Analizi Bütünleştiren Yaklaşım. (Çev. Edit. Turan, S.). Ankara: Nobel Akademik Yayıncilik. 
Göğebakan Yıldız, D. (2012). Kubaşık öğrenme ve anlaşmazlık çözümü eğitimi ile bütünleştirilmiş Türkçe ve sosyal bilgiler programının öğrencilerin akademik başarı, iletişim ve sosyal problem çözme becerilerine etkisi. Yayınlanmamış Doktora Tezi. Ege Üniversitesi Sosyal Bilimler Enstitüsü.

Gömleksiz, M. (1993). Kubaşık öğrenme yöntemi ile geleneksel yöntemin demokratik tutumlar ve erişiye etkisi. Yayınlanmamış Doktora Tezi. Çukurova Üniversitesi Sosyal Bilimler Enstitüsü. Adana.

Gürbüz, S. \& Şahin, F. (2016). Sosyal bilimlerde araştırma yöntemleri Felsefe-Yöntem-Analiz. Ankara: Seçkin Yayıncılık.

Karacaoğlu, Ö. C. \& Acar, E. (2010). Yenilenen programların uygulanmasında öğretmenlerin karşılaştığ1 sorunlar. Yüzüncü Yıl Üniversitesi Ĕ̆itim Fakültesi Dergisi, 7(1),45-58.

Karaoğlu, İ.B. (1998). Geleneksel öğretim yöntemleri ile işbirlikli öğrenmenin öğrenci başarısı, hatırda tutma ve sını yönetimi üzerindeki etkileri. Yayınlanmamış Doktora Tezi. Dokuz Eylül Üniversitesi Sosyal Bilimler Enstitüsü.

Karasar, N. (2012). Bilimsel araştırma yöntemi.(24. Basım).Ankara: Nobel Akademik Yayıncılık.

Kaşaveklioğlu, S. (2013). 7. sınıf sosyal bilgiler dersinde işbirliğine dayal öğretim yönteminin kullanılmasının öğrencilerin akademik başarı ile demokratik tutum ve insan hakları algılarına etkisi. Yayınlanmamış Yüksek Lisans Tezi. Gazi Üniversitesi Eğitim Bilimleri Enstitüsü.

Katılmış, A. (2002). İşbirlikli öğrenme ve geleneksel öğretim yöntemlerinin sosyal bilgiler dersi tarih konularındaki başarı ve hatırda tutma düzeyleri üzerindeki etkileri. Yayınlanmamış Yüksek Lisans Tezi. Marmara Üniversitesi Eğitim Bilimleri Enstitüsü.

Kılıç, H. (2006). İlköğretim 4. sınıf sosyal bilgiler dersinde kubaşık öğrenme yönteminin geleneksel küme çalışması yöntemine göre benlik saygısına ve akademik başarısına etkisi. Yayınlanmamış Yüksek Lisans Tezi. Çukurova Üniversitesi Sosyal Bilimler Enstitüsü.

Korkmaz Toklucu, S. (2013). İşbirliğine dayalı öğrenme yöntemi ile dizgeli eğitimin 4. sınıf sosyal bilgiler dersinde başarıya, kalıcılı̆̆a ve tutuma etkisinin karşılaştırılması. Yayınlanmamış Yüksek Lisans Tezi. Ahi Evran Üniversitesi Sosyal Bilimler Enstitüsü.

Kuş, Z. \& Çelikkaya, T. (2010). Sosyal bilgiler öğretimi için sosyal bilgiler öğretmenlerinin beklentileri. Yüzüncü Yıl Üniversitesi Eğitim Fakültesi Dergisi. Cilt: VII, Sayı: II, 69-91.

Kuş, Z. \& Karatekin, K. (2009). İşbirliğine dayalı öğrenmenin sosyal bilgiler dersinde akademik başarı üzerine etkisi. Uludă̆ Üniversitesi Eğitim Fakültesi Dergisi 22(2), 589604.

Kutay Atar, S. (2003). Sosyal bilgiler dersinde deprem konusunu işbirlikli öğrenme yöntemi ile öğretimin etkililiğinin araştırılması. Yayınlanmamış Yüksek Lisans Tezi. Marmara Üniversitesi Eğitim Bilimleri Enstitüsü.

Küçükilhan, S. (2013). Öğrenci Takımları - Başarı Bölümleri (ÖTBB) Tekniğinin Sosyal Bilgiler Dersindeki akademik başarıya ve kalıcılığa etkisi. Yayınlanmamış Yüksek Lisans Tezi. Afyon Kocatepe Üniversitesi Sosyal Bilimler Enstitüsü.

Meral, E. \& Şimşek, U. (2014). Sosyal bilgiler dersinde işbirlikli öğrenme yöntemlerinin 6. sınıf öğrencilerinin akademik başarılarına etkisi. Journal of Computer and Education Research, 2(4). 134-151. 
Oral, B. (2000). Sosyal bilgiler dersinde işbirlikli öğrenme ile küme çalışması yöntemlerinin öğrencilerin erişileri, derse yönelik tutumları ve öğrenilenlerin kalıcılığı üzerindeki etkileri. Çukurova Üniversitesi Ĕ̆itim Fakültesi Dergisi. 2(19), 43-49.

Öner, Ü. (2007). İlköğretim 7. sınıf sosyal bilgiler dersi tarih konularının öğretiminde işbirlikli öğrenme yönteminin öğrenci başarısına etkisi. Yayınlanmamış Yüksek Lisans Tezi. Fırat Üniversitesi Sosyal Bilimler Enstitüsü.

Özçelik, D. A. (1981). Okullarda ölçme ve değerlendirme. ÜSYM Eğitim Yayınları.

Özdemir, A. F. (2005). Sosyal bilgiler öğretiminde işbirliğine dayal öğrenme yönteminin ilköğretim 6. sını öğrencilerinin problem çözme başarısına etkisi. Yayınlanmamış Yüksek Lisans Tezi. Marmara Üniversitesi Eğitim Bilimleri Enstitüsü.

Özkal, N. (2000). İşbirlikli öğrenmenin sosyal bilgilere ilişkin benlik kavramı, tutumlar ve akademik başarı üzerindeki etkileri. Yayınlanmamış Doktora Tezi. Dokuz Eylül Üniversitesi Eğitim Bilimleri Enstitüsü.

Özkümüş (Yetkin), T. (2010). İlköğretim 4. sınıf sosyal bilgiler öğretiminde işbirlikli öğrenme yönteminin öğrencilerin akademik başarılarma ve derse yönelik tutumlarma etkisi. Yayınlanmamış Yüksek Lisans Tezi. Gazi Üniversitesi Eğitim Bilimleri Enstitüsü.

Sezer, A. ve Tokcan, H. (2003). İşbirliğine dayalı öğrenmenin coğrafya dersinde akademik başarı üzerine etkisi. Gü Gazi Eğitim Fakültesi Dergisi, 23(3), 227-242.

Slavin, R.E. (1981). Synthesis of research on cooperative learning. Retrieved from http://www.ascd.org/ASCD/pdf/journals/ed lead/el 198105 slavin.pdf 22/03/2017.

Slavin, R.E., Chamberlain, A. and Hurley, E. A. (2001). Cooperative learning in the social studies: Balancing the social and the studies. Retrieved from http://chandlercastle.weebly.com/uploads/1/3/5/9/13592554/cooperative learning in t he social studies balancing the social and the studies.pdf 22/03/2017.

Şimşek, A. (1990). Öğrenimde işbirliğinin yararları. M.Ü. Atatürk Eğitim Fakültesi Ĕ̆gitim Bilimleri Dergisi. 2, 187-202.

Şimşek, Ü. (2007). Çözeltiler ve kimyasal denge konularında uygulanan jigsaw ve birlikte öğrenme tekniklerinin öğrencilerin maddenin tanecikli yapıda öğrenmeleri ve akademik başarıları üzerine etkisi. Yayınlanmamış Doktora Tezi. Atatürk Üniversitesi Fen Bilimleri Enstitüsü. Erzurum.

Tekin, H. (2009). Ĕ̆itimde ölçme ve değerlendirme. Ankara: Yarg1 Yayınevi.

Turgut, M. F. (1977). Eğitimde ölçme ve değerlendirme metotları. Ankara: Nüve Matbaası.

Yıldırım, C. (Tarihsiz). Eğitimde ölçme ve değerlendirme (Öğretmenler için el kitabı). Hacettepe Sosyal ve İdari Bilimler Fakültesi Döner Sermaye İşletmesi.

Yılmaz, H. (1996). Ĕ̆itimde ölçme ve değerlendirme. Konya: Öz Eğitim Yayınları. 